\title{
Towards Optimal Treatment with Growth Hormone in Short Children and Adolescents: Evidence and Theses
}

\author{
Michael B. Ranke ${ }^{a}$ Anders Lindberg ${ }^{b}$ Primus E. Mullis ${ }^{c}$ Mitchell E. Geffner ${ }^{d}$ \\ Toshi Tanaka $^{\text {e }}$ Wayne S. Cutfield ${ }^{f}$ Maïthé Tauber ${ }^{g}$ David Dunger $^{\text {h }}$ \\ aPaediatric Endocrinology Section, Children's Hospital, University of Tuebingen, Tuebingen, Germany; \\ bPfizer Inc., Pfizer Endocrine Care, KIGS/KIMS/ACROSTUDY Medical Outcomes, Sollentuna, Sweden; \\ 'Division of Paediatric Endocrinology, Diabetology and Metabolism, Inselspital, University Children's Hospital, \\ Bern, Switzerland; ' Children's Hospital Los Angeles, Keck School of Medicine of USC, Los Angeles, Calif., USA; \\ eTanaka Growth Clinic, Tokyo, Japan; ${ }^{f}$ Liggins Institute, University of Auckland, Grafton, Auckland, New Zealand; \\ ${ }^{9}$ Centre de Référence du syndrome de Prader-Willi, Department of Endocrinology, Children's Hospital, Toulouse, France; \\ hUniversity Department of Paediatrics, University of Cambridge, Addenbrooke's Hospital, Cambridge, UK
}

\section{Key Words}

Growth hormone treatment · Efficacy · Cost-effectiveness ·

Optimization

\begin{abstract}
Treatment with growth hormone (GH) has become standard practice for replacement in GH-deficient children or pharmacotherapy in a variety of disorders with short stature. However, even today, the reported adult heights achieved often remain below the normal range. In addition, the treatment is expensive and may be associated with long-term risks. Thus, a discussion of the factors relevant for achieving an optimal individual outcome in terms of growth, costs, and risks is required. In the present review, the heterogenous approaches of treatment with $\mathrm{GH}$ are discussed, considering the parameters available for an evaluation of the short- and long-term outcomes at different stages of treatment. This discourse introduces the potential of the newly emerging prediction algorithms in comparison to other more conventional approaches for the planning and evaluation of the re-
\end{abstract}

sponse to $\mathrm{GH}$. In rare disorders such as those with short stature, treatment decisions cannot easily be deduced from personal experience. An interactive approach utilizing the derived experience from large cohorts for the evaluation of the individual patient and the required decision-making may facilitate the use of $\mathrm{GH}$. Such an approach should also lead to avoiding unnecessary long-term treatment in unresponsive individuals.

Copyright $\odot 2013$ S. Karger AG, Basel

\section{Introduction}

Growth hormone $(\mathrm{GH})$ has a long and complex history $[1,2]$. The era of GH treatment started when Raben [3] proved that replacement with pituitary-derived human GH was able to promote growth in a short adolescent with GH deficiency (GHD). However, during the first two decades, the experience with this treatment was hampered by the shortage of GH. After recombinant human GH (rhGH) became available in the 1980s, it was not

\section{KARGER}

E-Mail karger@karger.com

www.karger.com/hrp
(C) 2013 S. Karger AG, Basel

$1663-2818 / 13 / 0792-0051 \$ 38.00 / 0$
Prof. emer. Michael B. Ranke, FRCP (Edin)

Paediatric Endocrinology and Diabetology, University Children's Hospital Hoppe-Seyler-Strasse 1

DE-72076 Tuebingen (Germany)

E-Mail Michael.Ranke@med.uni-tuebingen.de 
only used for treatment of GHD, but successively also became an approved indication for a variety of disorders associated with short stature [4], most of which are not associated with impaired GH secretion. While it is today also recognized that severe GHD requires GH replacement during the whole life span [5], there is an ongoing debate over the justification of GH therapy for growth augmentation in non-GHD children [6]. The modalities of care during treatment with GH vary and there is neither evidence nor consensus about how to proceed $[7,8]$. The discussion about optimal rhGH therapy $[9,10]$ - particularly in non-GHD disorders - is fueled by several facts: (1) complete early catch-up growth and normal adult height are not always reached in many individuals with GHD and even less often in non-GHD individuals, (2) debate about the long-term safety of rhGH [9, 11-14], and (3) GH treatment remains quite expensive and strategies to optimize costs have not been developed. The aim of this article is to discuss strategies of treatment with $\mathrm{GH}$ in children and adolescents that are likely to give optimal results with regard to growth and to open views towards efficiency of GH use. The discussion is based on the experience with rhGH accumulated in recent decades and on recently developed growth response prediction algorithms [15].

\section{Decision-Making Process}

Before, during, and after GH therapy, a multitude of factors needs to be evaluated. The decision-making processes involves a number of considerations for the treating team, the patient, and his/her parents.

\section{Diagnosis of Growth Disorders}

Even though the issue of the diagnosis in disorders treated with GH is not the central theme of an article dealing with treatment, the appropriate diagnosis is the key for an adequate therapeutic result. The diagnosis drives the expectations and the interpretation of the growth response to GH. In particular, the diagnosis of GHD is a difficult one and needs to be based on anthropometrical and biochemical evaluations, as well as on imaging procedures and possibly on molecular genetic investigations $[16,17]$. Thorough and potentially repeated biochemical evaluation of $\mathrm{GH}$ secretion is particularly important in patients with presumed isolated congenital GHD. In some disorders with short stature for which GH is ap- proved, the diagnosis can be reliably made [Turner syndrome (TS), Silver-Russell syndrome, Prader-Willi syndrome, and SHOX (short stature homeobox gene on the $\mathrm{X}$-chromosome) haploinsufficiency], but in other disorders [e.g. small for gestational age (SGA) and idiopathic short stature (ISS)] the diagnosis is purely descriptive [18, 19]. The response to GH in treated patients may consequently be quite variable due to the heterogeneity of the underlying causes. There is the view that there is not only a continuum with respect to the diagnostic criteria, but also to the responsiveness to $\mathrm{GH}$ between isolated GHD, SGA, and ISS [20], which in effect would make a distinction between these entities unnecessary. Even if this were true, the use of $\mathrm{GH}$ is only authorized for specific indications (diagnoses) and the use of GH outside this framework may result in legal consequences for the prescriber due to 'off-label' prescribing.

\section{Safety of rhGH}

Although the safety of rhGH is very well documented during the childhood years $[21,22]$, there is an ongoing discussion about longer-term safety in terms of metabolic disorders and malignancies, particularly when used for statural indications other than GHD [12, 13, 23-25]. These concerns highlight the need for long-term surveillance of children treated with rhGH [26]. The information about rare but realistic short-term risks (e.g. benign increased intracranial hypertension, scoliosis, and slipped capital femoral epiphysis) as well as discussions about potential late effects need to be shared with parents and patients when GH therapy is under consideration. Foremost, the potential risks in an individual with a specific diagnosis need to be taken into consideration. If the individual's risk of treatment cannot be estimated with some certainty, the initiation of treatment may be reconsidered. The physician must also ensure that the patient/ family has a clear understanding of the general and specific side effects to GH that may occur during treatment. They also need to be instructed as to which actions can and will be taken in the case of any specific undesired event [27], even if is known to occur only rarely. Openness about potential problems is also the basis for a good relationship between the interacting parties that is the essential foundation for successful long-term therapy.

The identification of factors that would increase the risk of adverse effects from GH treatment is part of the diagnostic work-up after the cause of short stature has been established. It is obvious that the spectrum of investigations for the identification of underlying risk factors in a child with TS or after treatment for malignancies is
Ranke/Lindberg/Mullis/Geffner/Tanaka/ Cutfield/Tauber/Dunger 
different from those in isolated idiopathic GHD. Unfortunately, it still remains unclear which parameters should be monitored and how often during treatment in order to avoid side effects of GH. It appears intuitively sound that $\mathrm{GH}$ treatment should be conducted in a way so that any abnormality in body composition, functioning, or biochemistry is avoided. Whether the levels of GH-dependent parameters (e.g. IGF-I) can be used as a guide for safe GH treatment is still unclear [28, 29]. Long-standing high serum IGF-I levels should be avoided, but it is unclear what the limit should be [e.g. $>+2,+2.5$, or +3 SDS (SD score) for age] and for how long. In addition, the role of IGF-binding proteins in interpreting any adverse effect of IGF-I needs to be clarified. Likewise, it is still uncertain whether targeting the $\mathrm{GH}$ dose primarily according to IGF-I levels in GHD and non-GHD disorders $[30,31]$ is optimal for the safety of GH therapy in children and adolescents (see below; http://jcem.endojournals.org/cgi/ ijlink?linkType $=$ ABST \& journalCode $=$ endo\&resid $=$ 152/7/2546).

\section{Adherence/Compliance}

The correct interpretation of growth results requires that the patient comply with the recommended treatment. It is known that noncompliance with GH treatment is frequent [32] since the drug needs to be injected daily over many years and during different developmental stages of the child. In contrast to these difficulties, the psychological burden of being short varies and is often only moderate. In particular, there is no physical suffering or pain involved with short stature. Instruction regarding the technical aspects of GH injections, as well as the features of injection devices, may play a role in compliance $[33,34]$. Nonadherence has a proven negative impact on the outcomes of treatment [35]. There is presently no widely applied strategy to monitor rhGH treatment compliance [36].

Repeated measurements of GH-dependent parameters other than growth (e.g. serum IGF-I levels) appears, however, to be a more objective approach during followup than accounting for injections [37]. If an IGF-I level in a series of IGF-I measurements (within several weeks or months) on a constant GH dose is significantly lower than the others [38], impaired adherence can be assumed as the foremost cause. However, it is not absolutely clear what the expected IGF-I levels in an individual with a specific growth disorder on certain GH doses should be. An individual IGF-I target level could perhaps be established

Towards Optimal Treatment with GH in

Short Children and Adolescents by measuring IGF-I levels after a period of assured injections of GH, as in an IGF-I generation test [39]. In order to develop a realistic idea about an individual's target IGF-I level (or that of other GH-dependent peptides) while receiving $\mathrm{GH}$, measurements of such parameters should probably be done as part of a dose escalation program during the first 4 weeks of treatment [40] and then rechecking the levels at intervals of 3-6 months, or perhaps more often.

The strategies to improve adherence once an impairment has been established are complex [41] and not always successful. It is therefore of utmost importance to carefully instruct the patient and the family at the beginning of GH therapy of all aspects of treatment. A realistic expectation of the short- and long-term effects of therapy is one of the most important aspects to assure adherence to treatment. Consequences of suboptimal growth in response to $\mathrm{GH}$ with regard to further diagnostic measures and potential therapeutic consequences, including termination of treatment, should always be discussed before and repeatedly during therapy. Reducing visits with the treating physicians/team to the minimum (e.g. once a year) for the sake of cost is probably not helpful in promoting adherence to treatment. New modes of interaction between patients and physicians offered by information technology could be used in the future.

\section{Expected Long-Term Effect of GH Therapy}

For most growth disorders treated with $\mathrm{GH}$, data on adult height in groups of patients have been reported [4]. There is, however, no uniform consensus among physicians about what height should be achieved with GH and when GH treatment should be stopped. In GHD, a disorder which can be assumed to be of lifelong nature, treatment for stature may be continued as long as there is still growth potential. Whether it is justified to continue the childhood GH dose, which is higher than the GH doses recommended for the transition phase or in adult life [42], when approaching adult height should be considered.

It is not quite clear which parameters are the best to define the moment when to stop childhood GH replacement in GHD [43]. Commonly, in both GHD and in nonGHD short stature, it is assumed that near-adult height (NAH) is reached when the height velocity (HV) slows down below $2 \mathrm{~cm} /$ year and/or the remaining growth potential is in the order of $1-2 \%$ of adult height. The latter may be assumed when the bone age has reached 14 years 
in girls and 16 years in boys [44]. Still, under these conditions, the growth potential of adolescents may differ substantially between individuals. Biochemical markers released by the growing tissue (e.g. bone-specific alkaline phosphatase) may also be useful markers [45]. In GHD, the desired height should not only be within the normal range for the population, but also more importantly within the target range [46] for the family.

The criteria for when NAH is reached are probably very similar in GHD as well as in growth disorders with unimpaired GH secretion such as TS, SGA, chronic renal insufficiency, SHOX deficiency, and ISS. However, there is no consensus when $\mathrm{GH}$ treatment in these disorders should be stopped, with the views held by the patient and parents, the managing physician, and funding agency not always in alignment. Cessation points for rhGH include a desire by the patient to stop treatment, the lower limit of normal height for sex and the population, achievement of genetic height potential, and achievement of NAH. In clinical studies designed to gain evidence for the longterm efficacy of rhGH, patients are probably treated to $\mathrm{NAH}$ in order to explore the full potential of treatment. In a normal clinical setting, where the cost of GH may be borne by insurance companies or national health systems, treatment is probably stopped when the lower limit of normal adult height is approached (e.g. -2.0 SDS; 3rd centile $=-1.88$ SDS). It should also be considered that patients want to reach a height within or close to normality, irrespective of calculated height derivatives, such as parental target range, which may be of relevance only from a medical point of view.

There is currently a wealth of information about NAH reached with long-term $\mathrm{GH}$ treatment in groups of patients with GHD [47-49] and in various other disorders [50]. This allows counseling of patients/parents in a general way about the prospect of treatment. However, for advising the individual patient, it appears to be even more important to give information about the most likely height achievable given the individual circumstances and the most likely therapeutic strategies (including GH doses) at the beginning and to reassess during the course of treatment. Based on data from large cohorts, mathematical algorithms have been published that allow the calculation of the expected height - or gain in height - of children with GHD, TS, SGA, and ISS [47-53].

Some of the authors of this article (M.B.R. and A.L.) have been involved in the development of prediction models for children who have reached adult height and have been documented within KIGS [Pfizer International Growth Database, Pfizer Inc.; 53-57]. The details of the predictors and the parameter estimates of the prediction equations for GHD, TS, ISS, and SGA are summarized in table 1.

The algorithms shown in table 1 can be used to calculate the most likely achievable height given a certain constant GH dose within the approved range for the diagnosis. In table 2, there are three examples of children with TS, all with a projected adult height of $146.8 \mathrm{~cm}$ and who are expected to reach different adult heights based on differences in ages at onset of GH treatment, parental heights, GH doses, or levels of first-year growth responsive (see below) to $\mathrm{GH}$.

Obviously such calculations also need to consider the error of the long-term prediction and potentially other aspects (e.g. changes in dosing of GH or the timing of puberty) which may modify the results. Nonetheless, the figures will give all parties involved some realistic idea about the overall potential of GH treatment in an individual rather than adhering to general statements about results in groups of patients from randomized clinical trials or observational cohorts. This will influence the decision to start treatment in the first place and/or will affect the adherence to treatment once this decision to treat has been made.

\section{Short-Term Growth in Response to GH}

After the decision to treat a short child with GH has been made, several somewhat more technical, but important, aspects have to be considered: (1) GH dose and frequency, (2) how to express the response to $\mathrm{GH}$, (3) at which time intervals to evaluate the response to $\mathrm{GH},(4)$ how to evaluate the response to $\mathrm{GH}$, and (5) what the potential consequences of the observed growth (e.g. change in $\mathrm{GH}$ dose, stopping $\mathrm{GH}$, or other treatment) could be.

\section{Dose of GH and Frequency of Injections}

During the years of pituitary GH, injections were commonly given intramuscularly 2-3 times per week. However, it was subsequently shown that dividing the weekly dose into daily fractions gave superior growth results [59, 60 ] and that injecting $\mathrm{GH}$ by the subcutaneous route was no less effective [61].

In GHD, GH treatment is considered a replacement therapy. Here the dose required could be estimated based on the normal GH secretory rate in children of various ages, gender, and different developmental stages [62]. The studies to obtain approval of treatment with rhGH in
Ranke/Lindberg/Mullis/Geffner/Tanaka/ Cutfield/Tauber/Dunger 
Table 1. Prediction of NAH in various diagnoses [GHD including prediction of first-year growth (with or without maximum GH response to stimulation tests)]

\begin{tabular}{|c|c|c|c|c|c|}
\hline Diagnosis parameter & $\begin{array}{l}\text { GHD without } \\
\text { max. GH }\end{array}$ & $\begin{array}{l}\text { GHD with } \\
\text { max. GH }\end{array}$ & TS & ISS & SGA \\
\hline Intercept & 1.76 & 2.34 & -3.23 & 1.26 & 1.45 \\
\hline \multicolumn{6}{|l|}{ Parameter estimates } \\
\hline MPH, SDS (Pr) & 0.40 & 0.34 & 0.19 & 0.37 & 0.16 \\
\hline Ht-MPH, SDS (Pr) & - & - & - & - & - \\
\hline BW, SDS & 0.21 & 0.18 & - & - & - \\
\hline 1st-year SR without max. GH & 0.37 & - & 0.29 & 0.24 & 0.30 \\
\hline 1st-year SR with max. GH & - & 0.29 & - & & \\
\hline Mean GH dose, mg/kg/week & 1.15 & 1.28 & 0.98 & & 1.70 \\
\hline $\ln \max . \mathrm{GH}$ to tests, $\ln \mu \mathrm{g} / \mathrm{l}$ & - & -0.37 & - & & \\
\hline Age at GH start, years & -0.11 & -0.10 & -0.03 & -0.05 & -0.12 \\
\hline Frequency of injections/week, $\mathrm{n}$ & - & - & 0.17 & - & - \\
\hline
\end{tabular}

Calculation: $\mathrm{NAH}(\mathrm{SDS})=$ intercept $+($ parameter estimate $\mathrm{A} \times \mathrm{X})+($ parameter estimate $\mathrm{B} \times \mathrm{Y}) \ldots($ parameter estimate $\mathrm{Z} \times \mathrm{P}))$. $\mathrm{MPH}=$ Mid-parental height; BW = birth weight; $\mathrm{Pr}=$ Swiss references (Prader); max. GH = maximum GH levels to stimulation tests; $\mathrm{SR}=$ studentized residual; $\ln =$ natural logarithm.

${ }^{1}$ TS references $=$ Ranke.

GHD were originally conducted with dosages that were thought to reflect the daily $\mathrm{GH}$ production rate in prepubertal children. Accurate estimates of the amounts of GH secreted in prepubertal and pubertal children were, however, only possible by means of frequent sampling and deconvolution analyses [63-67]. However, these methods only became available after specific studies led to the approval of rhGH in GHD. In non-GHD disorders with short stature, the approved GH dosages were based on the doses used for phase III trials. In these studies, the dosages reflect the 'intelligent guesses' of the planners of such studies with regard to achieving the hypothesized effects of the trial. These doses are not necessarily the optimal ones for the intended effects. Moreover, based on the available data, the regulatory authorities in Europe, the USA, and Japan [68] have sometimes approved different doses for the treatment of the same diagnosis (e.g. SGA; table 3). Circumstances may also differ in other countries. It is also an open issue whether or not the individual GH dose should be calculated based on body weight or body surface area. However, the difference between the two approaches is only significant at the extremes of weight and in very young children where dosing should be based on body surface area.

Towards Optimal Treatment with GH in Short Children and Adolescents
Table 2. Examples of predicted adult height in patients with TS based on a KIGS long-term prediction model [58] (see table 1)

\begin{tabular}{llll}
\hline Turner syndrome & Case 1 & Case 2 & Case 3 \\
\hline Height at GH start, SDS (TS) & 0.0 & 0.0 & 0.0 \\
Projected adult height (TS ref.), cm & 146.8 & 146.8 & 146.8 \\
Age at GH start, years & 10 & 4 & 4 \\
MPH, SDS (Pr) & -1.0 & 0.0 & 1.0 \\
Mean GH dose, mg/kg/week & 0.29 & 0.29 & 0.35 \\
Frequency inj./week, n & 7 & 7 & 7 \\
1st-year SR (IoR) & -1.0 & 1 & 1 \\
Predicted adult height, SDS (Pr) & -2.54 & -1.87 & -1.34 \\
Predicted adult height, cm & 149.6 & 153.5 & 156.7 \\
Error, SD (cm) & 0.67 & 0.67 & 0.67 \\
& $(4.0)$ & $(4.0)$ & $(4.0)$ \\
Adult height $>$ 3rd centile of normal, & & & \\
$\quad$ probability \% & 25 & 50 & 75 \\
\hline
\end{tabular}

$\operatorname{Pr}=$ Swiss reference [59] (assumptions about 1st-year responsiveness made at $\mathrm{GH}$ start). IoR = Index of responsiveness. 
Table 3. GH doses recommended for different indications

\begin{tabular}{|c|c|c|c|c|}
\hline \multirow[t]{2}{*}{ Indication } & \multirow{2}{*}{$\begin{array}{l}\text { Europe (EMA) } \\
\mu \mathrm{g} / \mathrm{kg} / \text { day }\end{array}$} & \multirow{2}{*}{$\begin{array}{l}\text { Japan (PMDA) } \\
\text { mg/kg/week }\end{array}$} & \multicolumn{2}{|l|}{$\mathrm{USA}(\mathrm{FDA})^{1}$} \\
\hline & & & $\mathrm{mg} / \mathrm{kg} /$ week & $\mu \mathrm{g} / \mathrm{kg} / \mathrm{day}$ \\
\hline GHD & $25-35^{2}$ & 0.175 & $0.16-0.30^{2}$ & $23-43$ \\
\hline PWS & 35 & 0.245 & 0.24 & 34 \\
\hline TS & $45-50$ & 0.35 & $0.33-0.47$ & $47-67$ \\
\hline CRI & $45-50$ & $0.175-0.35$ & 0.35 & 50 \\
\hline SGA & 35 & $0.23-0.47$ & $0.47-0.48$ & $67-69$ \\
\hline SHOX haploinsufficiency & 50 & not approved & 0.35 & 50 \\
\hline ISS & not approved & not approved & $0.30-0.47$ & $43-67$ \\
\hline NS & not approved & not approved & up to 0.46 & up to 66 \\
\hline \multicolumn{5}{|c|}{$\begin{array}{l}\text { Not all brands have been approved for each indication. } \mathrm{GH} \text { dose }=\mathrm{mg} / \mathrm{kg} / \text { week: } 7=\mu \mathrm{g} / \mathrm{kg} / \mathrm{day} \text {. } \\
\text { PWS = Prader-Willi syndrome; CRI = chronic renal insufficiency; } \mathrm{NS}=\text { Noonan syndrome. } \\
{ }^{1} \text { Dose ranges reflect FDA-approved doses for same indication by different companies. } \\
{ }^{2} \text { May be increased in puberty in USA up to } 0.70 \mathrm{mg} / \mathrm{kg} / \text { week }(100 \mu \mathrm{g} / \mathrm{kg} / \mathrm{day}) .\end{array}$} \\
\hline
\end{tabular}

European and US practices $[8,69-71]$ show that physicians initially tend to treat with highly variable doses, which are usually less than those approved by the authorities. Whether this is done to give room for dose adaptation, because of fear of dose-associated side effects, because of cost consideration, and/or because of other reasons is unknown.

\section{Variables to Express the Short-Term Response to GH}

There are a variety of parameters that could be used to express the response to GH. Deriving accurate HV terms requires that patients are prepubertal at the start and at the end of the measurement period, and that reference data are available for the chronological age in question and not contaminated by pubertal individuals. The response is commonly given as $\mathrm{HV}$ expressed in terms of $\mathrm{cm} /$ year. The advantage of expressing HV in $\mathrm{cm}$ /year is that the term is 'pure' and not distorted by mathematical derivations. The calculation of this term requires two height measurements to be taken: the first at the start ( $\mathrm{t} 0)$ and second at the end of the observation phase (t1). The HV calculated is allotted to the arithmetic mean of the two time points $[(\mathrm{t} 0+\mathrm{t} 1) / 2]$ of chronological age measurements. However, the 'true' HV induced by GH would be the increment above the HV during the same time period without $\mathrm{GH}$ treatment. The difference between $\mathrm{HV}$ on $\mathrm{GH}$ and the HV before $\mathrm{GH}$ might give an approximation of the induced growth rate. Exact measurements of $\mathrm{HV}$ before $\mathrm{GH}$ replacement are often not available, not reliable, or sometimes not determined in order not to delay the start of treatment. To express HV independent of age and in relationship to normal sex-related references values, an SDS can be calculated [(HV measured - HV of reference for the same age)/SD of $\mathrm{HV}$ of reference]. In order to calculate this term, HV references based on longitudinal data need to be available. These are usually based on a relatively small sample size, which makes such a derived term quite inaccurate, particularly when the tempo of development (e.g. at puberty onset) does not follow the normal chronological pattern.

A comparatively more robust expression of the growth process is the change in height SDS (Ht SDS $\mathrm{t} 1-\mathrm{Ht}$ SDS t0). The calculation of this term requires height references for the calculation of height SDS. References of height for chronological age are usually based on large cohorts and thus provide robust references of means and SD for age. Prepubertal references can be extrapolated [72] from existing standards for children who are still prepubertal at ages when puberty has usually commenced. Thus, HV (cm/year) and change in height SDS $(\Delta \mathrm{Ht}$ SDS $)$ are the most appropriate parameters for describing a short-term response to GH. During GH treatment in the prepubertal years, both of these parameters are negatively correlated with age [73]. Maturational differences during the prepubertal years may partly be reflected by bone age $[74,75]$. However, there is no system based on evidence to incorporate this into the analysis of growth in response to $\mathrm{GH}$.
Ranke/Lindberg/Mullis/Geffner/Tanaka/ Cutfield/Tauber/Dunger 


\section{Intervals of Follow-Up}

The time which should elapse between the two height measurements depends on both the accuracy of the measurement and the HV [76]. At low velocities - given the same error of height measurement - the time elapsed between the measurements needs to be longer than on $\mathrm{GH}$ when HV increases. Thus, in order to assure an accurate determination of a $\mathrm{HV}$ before $\mathrm{GH}$ treatment, the time elapsed should be (6)-12 months [77]. On GH, it should at least be (3) -6 months. At the beginning of GH treatment, there is also a learning phase for the patient and parents. Therefore, it is probably too early to draw conclusions from HVs observed during the first 3 months of treatment. When response variables are based on data of measurements at start and after 12 months, very reliable information can be derived. During the prepubertal years, the references of height and HV are usually also established based on annual changes and published in relation to chronological age. There may be reasons to analyze growth while receiving $\mathrm{GH}$ in intervals longer than 1 year such as during puberty $[54,55]$, from the initiation of GH therapy to adult height (see above), or even considering the first two prepubertal years [78] together. Office visits are important for the interaction between physician and patient, which is the basis for understanding the problems and adherence to the advice given. We believe that there should be at least two follow-up visits at a growth center per year.

\section{How to Evaluate the Response to GH}

Statistically, normal HV (cm/year) for chronological age is defined as the range between the mean $\pm 2 \mathrm{SD}$. Before puberty, both the normal means and SD of $\mathrm{HV}(\mathrm{cm} /$ year) decrease with age. If the response variable is expressed in terms of SDS (HV SDS or $\triangle \mathrm{Ht}$ SDS), the normal range is defined as being between the mean (0.0 SDS) and \pm 2 SD. Usually, in patients with GHD, there is pronounced catch-up growth during the first year of $\mathrm{GH}$ treatment. The observed response parameters tend to be well above the normal range. During subsequent years, with nearing of height towards the individual target height and the concomitant fading of catch-up growth, response parameters tend to stabilize within the (upper) normal range. However, whether or not the magnitude of a response parameter reflects an 'adequate' growth response cannot be concluded from its face value. Since there is no known quantitative measure of an objectively adequate response to a dose of $\mathrm{GH}$ in an individual with a specific diagnosis, the interpretation of the observed response variable must be evaluated by comparison with references empirically derived from other comparable (i.e. equally defined diagnostic entity) individuals treated with GH.

For such a purpose, two separate approaches have been pursued: (1) establishing empirical growth references $[79,80]$ and (2) developing prediction models for the growth response [15].

\section{Empirical Growth References}

Empirical references for growth while receiving $\mathrm{GH}$ are based on the analysis of large cohorts of patients with a specific diagnosis. Individual responses [e.g. $\mathrm{HV}(\mathrm{cm} /$ year)] or $\Delta \mathrm{Ht}$ SDS of prepubertal patients treated with $\mathrm{GH}$ (e.g. GHD, TS, SGA, and ISS) during a certain phase of treatment (e.g. first or second year on $\mathrm{GH}$ ) were calculated. Observed data are summarized by transformation into means and SD - or centiles - in relationship to chronological age (and potentially gender). The observed response in an individual can be visualized when plotted onto the empirically derived reference charts. Individual responses expressed in terms of SDS can also be compared with corresponding reference values. The magnitude of such empirical references depends on the characteristics of the patients treated and the spectrum of the GH dose given. In the analysis based on the National Cooperative Growth Study (NCGS) experience in the USA [79], patients with GHD received $\mathrm{GH}$ at an average dose of 0.30 $\mathrm{mg} / \mathrm{kg} /$ week, while this dose was $0.22 \mathrm{mg} / \mathrm{kg} /$ week within the KIGS data base [58], which was predominantly derived from patients outside the USA. The GH doses for TS were the same in both surveillance studies $(0.30 \mathrm{mg} / \mathrm{kg} /$ week $)$. In the US study, first-year data for patients with idiopathic GHD, organic GHD, TS, and ISS were published [79]. In the KIGS study, prepubertal patients with idiopathic GHD were divided into those with 'severe' GHD (maximum GH in response to stimuli $<5 \mu \mathrm{g} / \mathrm{l}$ ) and 'less severe' GHD (maximum GH in response to stimuli 5-10 $\mu \mathrm{g} / \mathrm{l}$ ). In addition, children with TS or SGA were analyzed during the first two prepubertal years on GH. Unfortunately, the two studies are not directly comparable because the study based on US data does not give numerical results, but only graphic displays of first-year percentile charts. Additionally, the KIGS-based study does not provide information related to the sex of the individuals, although the height difference between males and females is only minimal during the prepubertal years. During the first year, the observed differences in HV ( $\mathrm{cm} /$ year) between the two stud- 
ies (mean levels for age) are small in idiopathic GHD $(<0.5$ $\mathrm{cm} /$ year $)$ and very small in girls with TS $(<0.3 \mathrm{~cm} /$ year $)$. Both groups of authors suggest that a HV or a $\Delta \mathrm{Ht}$ SDS below the 25th percentile for age (equivalent to an approximate mean of $<-1.0$ SDS) should be considered as an insufficient response. The error of the mean response (HV or $\Delta \mathrm{Ht} \mathrm{SD}$ ) for age in these empirical references (GHD, TS, or SGA) is in the order of $25 \%$ (coefficient of variation). The utility of empirical reference charts or calculated figures in daily practice appears to be evident. However, the response in an individual depends on the quantity of several individual factors, which may differ substantially from the average value of such factors reflected within the reference group (e.g. GH dose). For example, a patient receiving a low GH dose will typically show a low growth response compared to the empirical references. However, in this instance, the low response may be adequate.

\section{Short-Term Prediction Models}

Prediction models for a diagnostic entity are mathematical algorithms describing a response variable during a treatment phase with several independent variables (predictors) by means of a regression equation. Model development, which requires large patient groups, is either based on data from pharmacoepidemiological surveillances (NCGS, KIGS, and GeNeSIS) or from national cooperative studies [71, 81-89]. The relevant predictors are selected by multiple regression analyses out of a larger set of potential candidate variables to explain the greatest variability in response with the least error [88].

For the first prepubertal treatment years, such prediction algorithms have been derived and published by several groups of authors [83]. The approach for model development taken by the investigators varies considerably. Some models were developed for one diagnostic entity alone, while several diagnostic entities were considered together in other models. The response variables - HV and $\triangle \mathrm{Ht}$ SDS - were either considered for yearly periods or for the first 2 years of treatment together [84]. Predictors were either parameters available before or at the onset of treatment or during the first months on GH [85]. In some instances, all predictors were always available in each of the individuals taken in the regression analysis (e.g. all KIGS analyses), while some authors used specific analytical techniques to compensate for missing variables [85]. Since the GH dose is practically the only independent variable which can be modified by the treating physician, the practicality of a prediction model depends on
$\mathrm{GH}$ dose being one of the predictors. In the case that models are derived from study populations where the $\mathrm{GH}$ dose was uniform, the dose cannot be a parameter explaining part of the variability of a response. One of the most essential prerequisites for a prediction model is its validation on independent cohorts. The utility and acceptance of a prediction model as a clinical tool is determined by the easy availability of the independent variables, as well as the robustness (stability of the prediction in case of a measurement error of one predictor) and the easy calculability of the response variables. The lack of the latter has so far hampered the use and experience with existing prediction models by physicians.

The characteristics of KIGS prediction algorithms for the first year of GH treatment of children with GHD, TS, SGA, and ISS [83] are listed in table 4.

One way of describing the individual response in relationship to the reference cohort is the calculation of a studentized residual: [(observed - predicted)/error of predicted]. This studentized residual, which is an index of responsiveness', is a surrogate of the true responsiveness which could theoretically only be determined by a doseresponse analysis. This is not possible in a treated individual. The error of the mean prediction in GHD during the first year on $\mathrm{GH}$ is (coefficient of variation) about $15 \%$, a figure which is similar to that in prediction models for TS, SGA, and ISS based on KIGS data (table 4). Thus, the error is lower than that of an empirically derived response reference (see above). In the case of a positive figure of a studentized residual, the relative response of the individual investigated ('responsiveness') is better than the mean of the reference cohort; in the case of a negative figure, the opposite is the case.

The evaluation of response and responsiveness according to the underlying diagnosis appears to be most important during the first year of treatment. During the first year on $\mathrm{GH}$, a substantial fraction of the height deficit is recovered. In prediction models for growth during the following prepubertal years, the predictors are similar and have a similar degree of importance for the prediction of growth in idiopathic GHD, TS, SGA, or ISS [83]. The fact that first-year growth responsiveness (e.g. expressed in terms of the 'index of responsiveness') is an important predictor for both adult height and the total gain in height in several disorders [50, 51, 89] suggests that the responsiveness to $\mathrm{GH}$ is an inherent quality of an individual, which determines the long-term height outcomes in response to $\mathrm{GH}$. The causes of the variability of responsiveness, which may be genetic [90], need to be investigated in the future.
Ranke/Lindberg/Mullis/Geffner/Tanaka/ Cutfield/Tauber/Dunger 
Fig. 1. Response in two prepubertal children (table 5 boy A, big round symbol; boy $\mathrm{B}$, big square symbol) with GHD in relation to normal HV references (a), and normal HV references (b). Cloud: model patients with GHD.

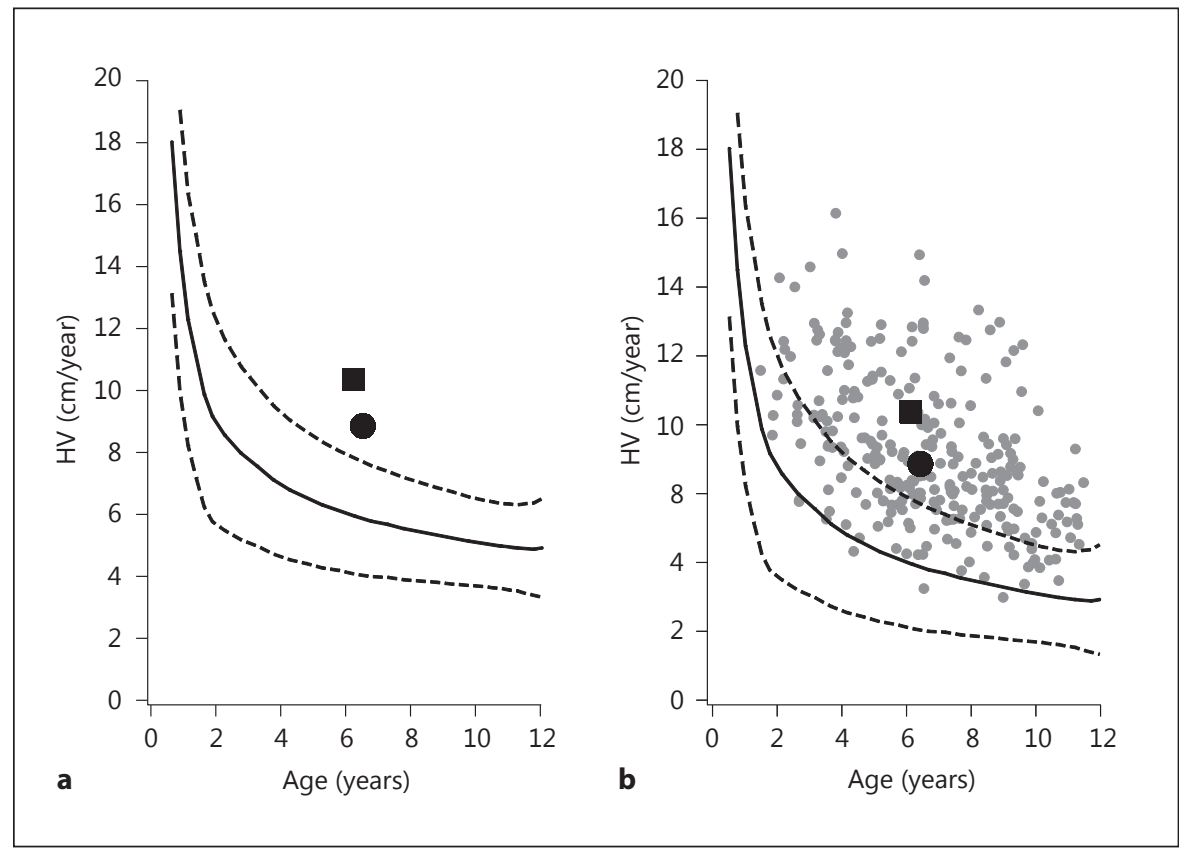

Table 4. Characteristics and parameter estimates of KIGS algorithms for predicting HV in prepubertal children treated with GH during the first year

\begin{tabular}{|c|c|c|c|c|c|c|c|c|c|c|c|}
\hline & Intercept & Age & BW & GH dose & GH inj. & Max. GH level & $\mathrm{Ht}-\mathrm{MPH}$ & $\mathrm{MPH}$ & Weight & Ox & $\begin{array}{l}\text { Error } \\
\text { SD }\end{array}$ \\
\hline IGHD & $\begin{array}{l}14.55 \\
12.41\end{array}$ & $\begin{array}{l}-0.32 \\
-0.36\end{array}$ & $\begin{array}{l}0.32 \\
0.47\end{array}$ & $\begin{array}{l}1.62^{\mathrm{a}} \\
1.54^{\mathrm{a}}\end{array}$ & & -1.37 & $\begin{array}{l}-0.40 \\
-0.60\end{array}$ & & $\begin{array}{l}0.29 \\
0.28\end{array}$ & & $\begin{array}{l}1.46 \\
1.72\end{array}$ \\
\hline TS & 8.09 & -0.28 & & $2.19^{\mathrm{a}}$ & 0.38 & & -0.24 & & 0.43 & 1.60 & 1.26 \\
\hline SGA & 9.39 & -0.31 & & $56.51^{\mathrm{b}}$ & & & & 0.11 & 0.30 & & 1.35 \\
\hline
\end{tabular}

Age: years; BW: in SDS; GH dose: IU/kg/week; GH inj.: injections in n/week, Max. GH level: ln $\mu$ g/l; Ht - MPH: in SDS; MPH: in SDS; Ox: yes = 1; Error SD: in cm. Example: for a patient with IGHD, in the 1st year the equation is: HV $(\mathrm{cm} / \mathrm{year})=14.55+($ age at onset [years] $\times-0.32)+(\mathrm{BW}[\mathrm{SDS}] \times 0.32)+(\mathrm{GH}$ dose $[\ln \mathrm{IU} / \mathrm{kg} /$ week] $\times 0.62)+($ maximum GH in response to stimulation $[\mathrm{ln} \mu \mathrm{g} / \mathrm{l} \times$ $-1.37]+(\mathrm{Ht}-\mathrm{MPH}[\mathrm{SDS}] \times-0.40)+($ weight $[\mathrm{SDS}] \times 0.29)$; - error SD $=1.46(\mathrm{~cm})$. IGHD = Idiopathic growth hormone deficiency.

${ }^{\mathrm{a}} \mathrm{GH}$ dose $\mathrm{ln}$ (IU/kg/week); ${ }^{\mathrm{b}} \mathrm{GH}$ dose (mg/kg/day); ${ }^{\mathrm{c}} \mathrm{GH}$ dose (mg/kg/week).

In the case of a response and 'responsiveness' greater than expected, it can be assumed that the individual will grow well, even with less GH. In this situation, a reduction of the GH dose may be possible. In the case of a reduced response and 'responsiveness' - provided lack of adherence is excluded - unknown causes of impaired growth may be found and excluded. However, the patient may also be insensitive to $\mathrm{GH}$ and an increase of the $\mathrm{GH}$ dose or even a continuation of GH may be ineffective since no substantial gain in height can be achieved with GH. An increase in GH dosing (within the frame of that approved) is only meaningful when a patient exhibits an insufficient response but normal responsiveness and a good growth potential to GH. A normal response may also mask an inappropriate responsiveness (examples illustrated in table 5 and fig. $1 \mathrm{a}, \mathrm{b} ; 2 \mathrm{a}, \mathrm{b} ; 3)$ in an individual. The optimal choice of the GH dose in relationship to the observed and expected growth during the prepubertal years may require algorithms for the prediction of height over several years that are easily accessible to the physician [91]. 
Fig. 2. Response in two prepubertal children with GHD (table 5 boy A, big round symbol; boy B, big square symbol) in comparison with empirical HV reference ranges of children with severe GHD (a) and empirical $\mathrm{HV}$ reference ranges of children with less severe GHD (b) (lines mark +2 , $+1,0,-1,-2$ SDS, respectively).

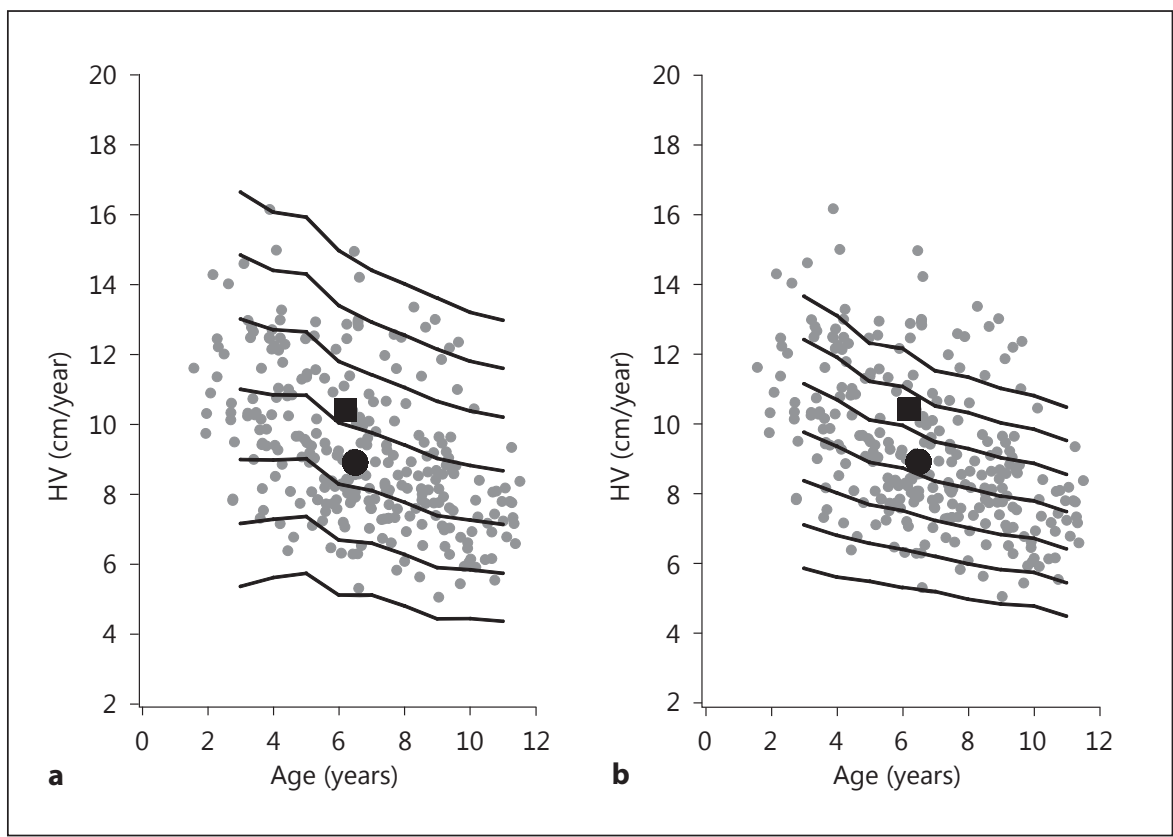

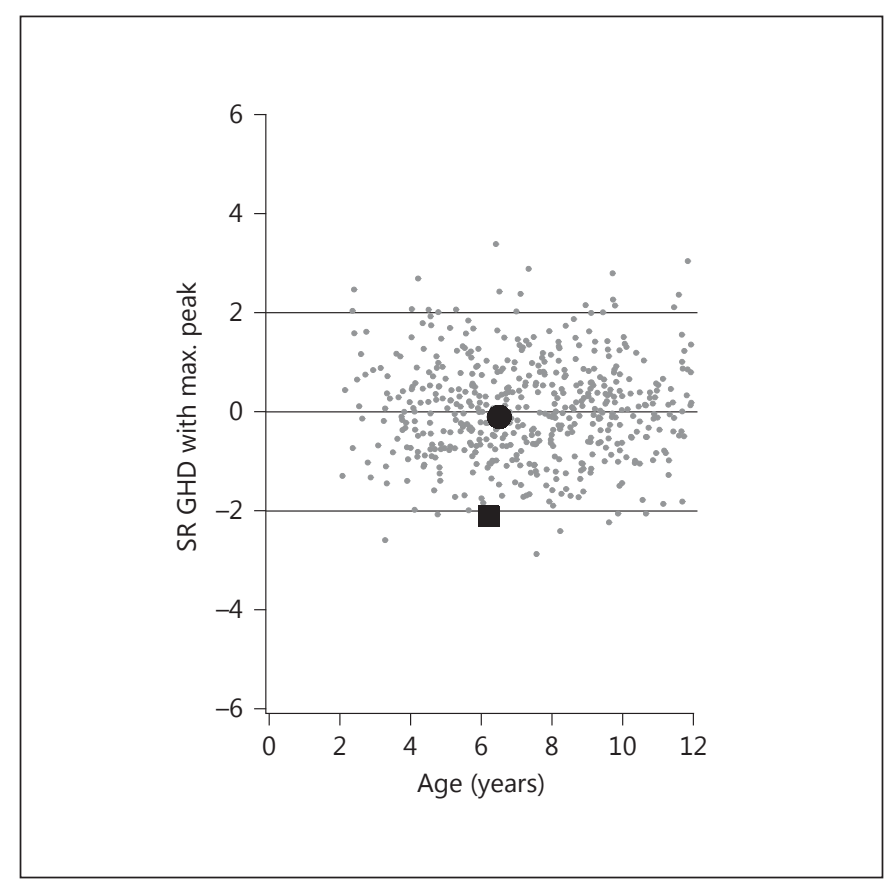

Fig. 3. Studentized plot indicating the 'index of responsiveness' (yaxis) in 2 children with GHD (boy A, big round symbol; boy B, big square symbol) treated with GH during the first prepubertal year with $\mathrm{GH} . \mathrm{SR}=$ Studentized residual.
Table 5. Examples of expressing and visualizing the response to $\mathrm{GH}$ in 2 (A/B) individuals with GHD

\begin{tabular}{llll}
\hline Parameter & $\begin{array}{l}\text { Model pa- } \\
\text { tients }(\mathrm{n}= \\
521 ; \text { median }\end{array}$ & $\begin{array}{l}\text { GHD } \\
\text { patient } \\
\text { A (boy) }\end{array}$ & $\begin{array}{l}\text { GHD } \\
\text { patient } \\
\text { B (boy) }\end{array}$ \\
\hline Age, years & 7.3 & 7.0 & 6.7 \\
Height, SDS & -3.2 & -3.0 & -1.8 \\
MPH, SDS & -1.2 & -1.0 & +0.5 \\
Ht - MPH & -2.0 & -2.0 & -2.3 \\
BW, SDS & -0.6 & -0.6 & -0.5 \\
Weight, SDS & -3.0 & -3.0 & -1.1 \\
Max. GH, $\mu$ g/l & 6.0 & 6.0 & 0.2 \\
GH dose, mg/kg week & 0.19 & 0.18 & 0.26 \\
\multicolumn{1}{c}{$\mu$ g/kg day } & 27 & 25 & 37 \\
Observed HV 1st year, cm/year & 9.0 & 8.9 & 10.4 \\
Predicted HV 1st year, cm/year & 9.0 & 8.8 & 14.5 \\
Index of responsiveness & 0.0 & -0.1 & -2.1 \\
Observed $\Delta$ Ht, SDS & 0.80 & 0.76 & +1.1 \\
\hline
\end{tabular}

\section{IGF-I Levels for the Evaluation of Safety and Efficacy}

The potential role of IGF-I as an indicator of adherence to treatment has been discussed above as it is closely associated with the GH dose. Like with the growth response to $\mathrm{GH}$, the quantitative dose-response relationship between GH and IGF-I (and probably other GHdependent IGF-related parameters) depends on the diag-
Ranke/Lindberg/Mullis/Geffner/Tanaka/ Cutfield/Tauber/Dunger 
Table 6. Pretreatment strategy

\begin{tabular}{ll}
\hline Diagnostic path & $\begin{array}{l}\text { clinical, anthropometrical, radiological, and biochemical work-up with standardized methods; in } \\
\text { suspected disorders of the GH-IGF axis, but uncertain test results, repeat investigations; establish } \\
\text { causality of growth disorder }\end{array}$ \\
\hline GH status of diagnosis & GHD disorder vs. non-GHD disorder \\
\hline Approval of GH & GH approved vs. GH not approved \\
\hline Outcomes, spontaneous & estimate of spontaneous adult height without GH treatment/replacement \\
\hline Outcomes, with GH & estimate potential of individual adult height/gain in height (long-term prediction) \\
\hline Risk assessment & $\begin{array}{l}\text { attempt an estimate of individual risk of GH treatment; investigate disease-specific risk factors; action } \\
\text { plan in case of side effects }\end{array}$ \\
\hline Treatment decision & follow-up plan (see below) \\
\hline GH brand & choose GH formulation and injection device \\
\hline GH dose & choose starting GH dose (within approved dose range) \\
\hline Estimate 1st-year growth & $\begin{array}{l}\text { predict 1st-year growth response; action plan for deviation from expected growth; discuss exit scenario } \\
\text { with patient }\end{array}$ \\
\hline
\end{tabular}

nosis. In addition, there is a relationship between the magnitude of gain in height and IGF-I levels. Whether growth response parameters are mostly correlated with the change in IGF-I over basal levels [92-94], with the maximum IGF-I level attained on GH, or with both parameters, is not fully clarified [95]. Thus, the interrelationship between GH dose, growth, and IGF-I levels remains somewhat obscure. Any attempt to better understand the problem requires, in the first place, that components of the IGF system are measured exactly and that age- and sex-related references are available for comparison [96, 97].

The discussion about the role of IGF-I measurements during GH therapy has been stimulated by reports [98] which suggest that, in patients with GHD, the growth response can be optimized based on serum IGF-I (and IGFBP-3) levels during the first (two) prepubertal years on GH. The study by Cohen et al. [95] was based on observations in children with GHD who were randomized to 25,50 , or $100 \mu \mathrm{g} / \mathrm{kg} /$ day of $\mathrm{GH}$. The main theses of the authors is that the IGF-I level may be more important than the $\mathrm{GH}$ dose in determining the growth response and that the GH dose could be adapted such that growth was maximal while IGF-I levels remained within certain limits for age and sex. Even though GH doses are limited by regulatory bodies (table 3 ), the idea should be given serious consideration. Children with low response and responsiveness whose IGF-I levels remain low or do not increase adequately on $\mathrm{GH}$ must be considered to be $\mathrm{GH}$ insensitive and may need be taken off GH. Children with an inappropriate growth response to a certain GH dose, but normal responsiveness, may receive additional $\mathrm{GH}$ as long as the resulting IGF-I level remains in the normal range. Children with exceedingly high IGF-I levels (e.g. $>+2.3 \mathrm{SDS}=99$ th centile) - irrespective of their response or responsiveness - should receive less GH (e.g. stepdown in the GH dose by about $20 \%$ per step; IGF-I control after 4-12 weeks). Even though the IGF-I level during the first year of GH therapy depends on the diagnosis and the $\mathrm{GH}$ dose, there is considerable uniformity with regard to the $\triangle$ IGF-I SDS (before and on GH) between groups of patients with different diagnoses receiving different approved doses of GH $[99,100]$. These data suggest that an increment above basal levels of IGF-I $<1.0$ SDS is likely to be insufficient during the first year of GH treatment. However, further studies need to be conducted in different diagnostic categories including standardized measurements of IGF-axis components.

\section{GH Dosing according to Individual Responsiveness}

In two studies so far, attempts have been made to prove that optimization of GH treatment is possible when information from a growth prediction model is considered. Kriström et al. [100] treated a group of children with GHD and ISS with GH over 2 prepubertal years. The patients were randomized to receive either a standard dose 
Table 7. First year on GH and prepubertal follow-up strategy

\begin{tabular}{|c|c|}
\hline At start & $\begin{array}{l}\text { assure that all parameters required for establishing diagnosis and risks of treatment and for follow-up are } \\
\text { documented (preserved) }\end{array}$ \\
\hline First weeks on GH & $\begin{array}{l}\text { assure injections of GH during initial week; measure biochemical parameters of response and adherence } \\
\text { thereafter (e.g. IGF-I and 'IGF-I generation test') }\end{array}$ \\
\hline First year on GH & $\begin{array}{l}\text { follow-up at 3, 6, (9), and } 12 \text { months [clinical and biochemical parameters of response/adherence (e.g. IGF-I)]; if } \\
\text { not indicated, do not change GH dose during first year }\end{array}$ \\
\hline $\begin{array}{l}\text { Disease-specific } \\
\text { empirical } \\
\text { references }[79,80]\end{array}$ & $\begin{array}{l}\text { disease-specific references available (response): } \\
\text { a 'normal' growth }=-1.0 \text { to }+1.0 \text { SDS or } 25 \text { th to } 75 \text { th centile } \\
\text { b 'poor' growth }=<-1.0 \text { SDS or }<25 \text { th centile } \\
\text { c 'good' growth }=>+1.0 \text { SDS or }>75 \text { th centile } \\
\text { disease-specific references (non-GHD) not available: } \\
\text { use SGA references as an estimate }\end{array}$ \\
\hline $\begin{array}{l}\text { Adult height } \\
\text { prediction }\end{array}$ & $\begin{array}{l}\text { calculate predicted adult height based on observed 1st-year IoR: } \\
\text { a if adult height prognosis normal and IGF-I SDS levels within upper norm }(>0.0<+2.0 \text { SDS), continue with } \\
\text { same dose } \\
\text { b if adult height prognosis poor ( }<-2.0 \text { SDS) and IGF-I SDS levels low ( }<0.0 \text { SDS), increase GH dose (up to } \\
\text { approved limits) }\end{array}$ \\
\hline $\begin{array}{l}\text { Considerations } \\
\text { according to } \\
\text { response and IoR }\end{array}$ & $\begin{array}{l}\text { a response and responsiveness (IoR): 'poor': } \\
\Delta \text { IGF-I on GH <0.5 SDS } \\
\text { consider GH resistance, if adherence assured } \\
\text { consider end of GH treatment } \\
\text { b IGF-I on GH > 1.0 SDS } \\
\text { consider IGF resistance } \\
\text { consider ending GH treatment } \\
\text { response 'normal' and responsiveness (IoR) poor: } \\
\text { reconsider diagnosis } \\
\text { response 'poor' and responsiveness (IoR) normal: } \\
\text { consider increasing GH dose } \\
\text { response and responsiveness (IoR): good: } \\
\text { a IGF-I SDS levels >+2.0 SDS: reduce GH dose by 20\%, follow IGF within } 1-3 \text { months } \\
\text { b IGF-I SDS levels normal and adult height prognosis good: consider reducing GH dose by 20\%, follow IGF-I } \\
\text { within } 1-3 \text { months }\end{array}$ \\
\hline $\begin{array}{l}\text { Subsequent } \\
\text { prepubertal years }\end{array}$ & $\begin{array}{l}\text { use empirical growth references and prediction models, if available; keep height, response variables, and IoR } \\
\text { within normal range }\end{array}$ \\
\hline
\end{tabular}

of $\mathrm{GH}(43 \mu \mathrm{g} / \mathrm{kg} /$ day) or to an individualized GH dose (17-100 $\mu \mathrm{g} / \mathrm{kg} /$ day). In the individualized group, the dose was chosen according to the predicted height (the lower the predicted height, the more GH recommended). By doing this, the number of children with poor outcomes was significantly reduced. In the study of Jung et al. [101], children with SGA were randomized into two groups: one received GH at a fixed dose of $67 \mu \mathrm{g} / \mathrm{kg} /$ day for 1 year, while the other group received $35 \mu \mathrm{g} / \mathrm{kg}$ day at the start. After 3 months, a prediction of the 12-month growth rate was conducted. In the case of an expected gain in height of $>0.75$ SDS, the dose was continued, but at a lower predicted gain the dose was increased to the fixed dose. Both groups had similar height responses after 1 year. Such
Ranke/Lindberg/Mullis/Geffner/Tanaka/ Cutfield/Tauber/Dunger 
Table 8. At puberty onset

\begin{tabular}{|c|c|}
\hline $\begin{array}{l}\text { Puberty } \\
\text { onset }\end{array}$ & $\begin{array}{l}\text { if spontaneous pubertal onset precocious, treat accordingly } \\
\text { if spontaneous pubertal onset delayed, consider induction of puberty }\end{array}$ \\
\hline $\begin{array}{l}\text { Expected } \\
\text { adult height }\end{array}$ & $\begin{array}{l}\text { Calculate expected total pubertal growth based on prediction models (if available) or prediction systems based on bone } \\
\text { age } \\
\text { a if expected adult height within the normal range: } \\
\text { continue prepubertal GH dose } \\
\text { b if expected adult height below normal range: } \\
\text { estimate further gain of height by increasing to pubertal GH dose } \\
\text { if normalization of adult height not likely by pubertal GH dose, consider additional medication to delay puberty }\end{array}$ \\
\hline
\end{tabular}

studies need to be continued in order to strengthen the evidence that a modification of treatment based on responsiveness will improve adult height outcomes.

\section{Pubertal Growth}

The determination of the magnitude of pubertal growth itself is complex. Depending on whether the onset of puberty is defined by pubertal stages (Tanner), which is common in clinical practice, or by the analysis of the growth process [102], different results are obtained in spontaneously developing children and in children treated with GH [103]. Pubertal growth is the result of the interaction between sex steroids and the GH-IGF system, and the tissues affected by these hormones [104]. In children who also have additional hypogonadism (GHD and TS), the timing of induction of puberty should be oriented toward (late-) normal development. The complex modalities of treatment, which are not the specific target of this article, should aim at imitating normal puberty [105107].

In healthy adolescents, the magnitude of pubertal growth of an individual depends on the distance between the height reached at puberty onset and the target height [108]. A child with a given target height will grow more during puberty when its onset is at an earlier age (or bone age) and at a lower height than a child with the same target height who is older and taller at pubertal onset. The same principle is valid during treatment with GH in short children [109]. GH secretion and IGF-I levels are considerably higher during puberty, which may aid GH treatment during this phase of development. However, while the growth response to $\mathrm{GH}$ during puberty is dose-dependent, the dose effect is surprisingly small given the dramatic increase of the hormones in the GH-IGF axis during

Towards Optimal Treatment with GH in

Short Children and Adolescents this phase. In a study by Mauras et al. [110], the doubling of the prepubertal GH dose in adolescents with GHD during 3 years of puberty only resulted in an additional gain of $4.2 \mathrm{~cm}$. Mathematical algorithms describing growth during puberty while on GH therapy in GHD, TS, SG, and ISS confirm that the role of GH on growth is minor during this period [109]. Since patients are heavier/taller during puberty, the gain achieved with GH is also much more expensive than during the prepubertal years. Thus, any dose increase during puberty needs to be based on its potential benefit which can be estimated by utilizing prediction algorithms at the onset of puberty. The analysis of the cost:benefit ratio becomes a more relevant issue during puberty. Since the height (SDS) reached at puberty onset correlates highly with adult height, the attempt to normalize height should focus on the prepubertal years. In growth disorders not associated with GHD, studies should be conducted to determine how much $\mathrm{GH}$ is required to maintain a degree of pubertal growth sufficient to reach a normal adult height once normalization of height for age (developmental stage) has been reached at puberty onset. Some but not all investigators suggest that additional gain in height can be achieved by medically suppressing puberty in cases with an unfavorable height prognosis [110$114]$, but this is not routine practice.

\section{Proposed Treatment Algorithms}

To conclude, the authors suggest that the treatment process with GH should take into consideration a multitude of aspects in a stepwise and structured fashion. Therefore, we have devised algorithms (table 6-8) for various phases and aspects of this process. For a process as complex as the treatment with $\mathrm{GH}$ in a multitude of diagnoses and developmental phases of childhood and 
adolescence, these algorithms may not consider all relevant aspects. However, they may guide the physician towards a more optimal treatment.

\section{Disclosure Statement}

M.B.R. has been a member of the KIGS board and received lecture fees from Pfizer, Novo Nordisk, E. Lilly, and Ipsen. W.S.C. has a consultancy with GenSci for national growth database establish- ment. M.T. received lecture fees from Pfizer and Novo Nordisk and is on a Pfizer and Ipsen advisory board.

M.E.G. has a research grant and research contract from Eli Lilly Inc.; a research grant from Genentech Inc.; is on a data safety monitoring board and has a research contract from Ipsen; is on an advisory board for Merck-Serono; has a research grant and research contract from Novo Nordisk; and has a research grant and research contract from, and is on an advisory board for, Pfizer Inc. P.E.M. and T.T. have nothing to disclose.

Editorial assistance was provided by Margaretha Lindell.

\section{References}

1 Tattersall R: A history of growth hormone. Horm Res 1996;46:236-247.

2 Lindholm J: Growth hormone: historical notes. Pituitary 2006;9:5-10.

-3 Raben MS: Treatment of a pituitary dwarf with human growth hormone. J Clin Endocrinol Metab 1958;18:901-903.

4 Richmond E, Rogol A: Current indications for growth hormone therapy for children and adolescents; in Hindmarsh PC (ed): Current Indications for Growth Hormone Therapy, ed 2, revised. Basel, Karger, 2010, vol 18, pp 92-108.

5 Clayton PE, Cuneo RC, Juul A, Monson JP, Shalet SM, Tauber M, European Society of Paediatric Endocrinology: Consensus statement on the management of the GH-treated adolescent in the transition to adult care. Eur J Endocrinol 2005; 152:165-170.

-6 Allen DB: Clinical review: lessons learned from the hGH era. J Clin Endocrinol Metab 2011;96:3042-3047.

7 Juul A, Bernasconi S, Clayton PE, Kiess W, DeMuinck-Keizer Schrama S, Drugs and Therapeutics Committee of the European Society for Paediatric Endocrinology (ESPE): European audit of current practice in diagnosis and treatment of childhood growth hormone deficiency. Horm Res 2002;58:233241.

8 Miller BS, Shulman DI, Shillington A, Harshaw Q, Wilson DM, Schwartz D, Kappy M, Bakker B, Wyatt D: Consensus and discordance in the management of growth hormone-treated patients: results of a knowledge, attitudes, beliefs, and practices survey. Int Pediatr Endocrinol 2010;2010:891571.

9 Wit JM: Growth hormone therapy. Best Pract Res Clin Endocrinol Metab 2002;16:483-503.

10 Wit JM: Optimizing growth hormone therapy in growth hormone deficient children: what to do in the absence of hard evidence? Horm Res 2007;68:244-247.

-11 Carel JC, Butler G: Safety of recombinant human growth hormone. Endocr Dev 2010;18: $40-54$.
12 Allen DB: Safety of growth hormone treatment of children with idiopathic short stature: the US experience. Horm Res Paediatr 2011;76(suppl 3):45-47.

13 Sävendahl L, Maes M, Albertsson-Wikland K, Borgström B, Carel JC, Henrard S, Speybroeck N, Thomas M, Zandwijken G, Hokken-Koelega A: Long-term mortality and causes of death in isolated GHD, ISS, and SGA patients treated with recombinant growth hormone during childhood in Belgium, the Netherlands, and Sweden: preliminary report of 3 countries participating in the EU SAGhE study. J Clin Endocrinol Metab 2012;97:E213-E217.

14 Carel JC, Ecosse E, Landier F, MeguellatiHakkas D, Kaguelidou F, Rey G, Coste J: Long-term mortality after recombinant growth hormone treatment for isolated growth hormone deficiency or childhood short stature: preliminary report of the French SAGhE study. J Clin Endocrinol Metab 2012; 97:416-425.

15 Ranke MB, Lindberg A: Predicting growth in response to growth hormone treatment. Growth Horm IGF Res 2009;19:1-11.

16 Webb EA, Dattani MT: Diagnosis of growth hormone deficiency. Endocr Dev 2010;18:5566.

17 Ranke MB: Growth hormone deficiency: diagnostic principles and practice; in Ranke MB, Mullis PE (eds): Diagnostics of Endocrine Function in Children and Adolescents, ed 4. Basel, Karger, 2011, pp 102-137.

18 Caliebe J, Martin DD, Ranke MB, Wit JM: The auxological and biochemical continuum of short children born small for gestational age (SGA) or with normal birth size (idiopathic short stature). Int J Pediatr Endocrinol 2010;2010:852967.

19 Wit JM: Definition and subcategorization of idiopathic short stature: between consensus and controversy. Horm Res Paediatr 2011; 76(suppl 3):3-6.

20 Wikland KA, Kriström B, Rosberg S, et al: Validated multivariate models predicting growth response to GH treatment in individual short children with a broad range in $\mathrm{GH}$ secretion capabilities. Pediatr Res 2000;48: 475-484.
21 Bell J, Parker KL, Swinford RD, Hoffman AR, Maneatis T, Lippe B: Long-term safety of recombinant human growth hormone in children. J Clin Endocrinol Metab 2010;95:167177.

22 Wilton P, Mattsson AF, Darendeliler F: Growth hormone treatment in children is not associated with an increase in the incidence of cancer: experience from KIGS (Pfizer International Growth Database). J Pediatr 2010; 157:265-270.

23 Ergun-Longmire B, Mertens AC, Mitby P, Qin J, Heller G, Shi W, Yasui Y, Robison LL, Sklar CA: Growth hormone treatment and risk of second neoplasms in the childhood cancer survivor. J Clin Endocrinol Metab 2006;91:3494-3498.

24 Wilton P: Adverse events reported in KIGGS; in Ranke MB, Price DA, Reiter EO (eds): Growth Hormone Therapy in Pediatrics - 20 Years of KIGS. Basel, Karger, 2007, pp 432441.

25 Carel JC, Ecosse E, Landier F, MeguellatiHakkas D, Kaguelidou F, Rey G, Coste J: Long-term mortality after recombinant growth hormone treatment for isolated growth hormone deficiency or childhood short stature: preliminary report of the French SGA study. J Clin Endocrinol Metab 2012;97: 416-425.

26 Rosenfeld RG, Cohen P, Robinson LL, Bercu BB, Clayton P, Hoffman AR, Radovick S, Saenger P, Savage MO, Wit JM: Long-term surveillance of growth hormone therapy. J Clin Endocrinol Metab 2012;97:68-72.

27 Biannual Report No. 17; Pfizer \& Upjohn International Growth Study 2000 - ISSN-11029587;ISRN GHF-KIGS-R-17-SE.

28 Cohen P, Clemmons DR, Rosenfeld RG: Does the GH-IGF axis play a role in cancer pathogenesis? Growth Horm IGF Res 2000;10:297305

29 Gallagher EJ, LeRoith D: Minireview: IGF, insulin, and cancer. Endocrinology 2011;152: 2546-2551. 
30 Cohen P, Rogol AD, Howard CP, Bright GM, Kappelgaard AM, Rosenfeld RG, American Norditropin Study Group: Insulin growth factor-based dosing of growth hormone therapy in children: a randomized, controlled study. J Clin Endocrinol Metab 2007;92: 2480-2486.

31 Baron J: Editorial: growth hormone therapy in childhood: titration versus weight-based dosing? J Clin Endocrinol Metab 2007;92: 2436-2438.

32 Rosenfeld RG, Bakker B: Compliance and persistence in pediatric and adult patients receiving growth hormone therapy. Endocrine Pract 2008;14:143-154.

33 Kirk J: Improving adherence to GH therapy with an electronic device: first experience with Easypod. Pediatr Endocrinol Rev 2009; 6(suppl 4):549-552.

- 34 Cázares-Delgadillo J, Ganem-Rondero A, Kalia YN: Human growth hormone: new delivery systems, alternative routes of administration, and their pharmacological relevance. Eur J Pharm Biopharm 2011;78:278-288.

- 35 Cutfield WS, Derraik JG, Gunn AJ, Reid K, Delany T, Robinson E, Hofman PL: Noncompliance with growth hormone treatment in children is common and impairs linear growth. PLoS One 2011;6:e16223.

- 36 Kapoor RR, Burke SA, Sparrow SE, Hughes IA, Dunger DB, Ong KK, Acerini CL: Monitoring of concordance in growth hormone therapy. Arch Dis Child 2008;93:147-148.

- 37 Pawlikowska-Haddal A, Cohen P, Cook DM: How useful are serum IGF-I measurements for managing GH replacement therapy in adults and children? Pituitary 2011;15:126134.

38 Harris EK, Yasaka T: On the calculation of a 'reference change' for comparing two consecutive measurements. Clin Chem 1983;29:2530.

-39 Buckway CK, Guevara-Aguirre J, Pratt KL, Burren CP, Rosenfeld RG: The IGF-I generation test revisited: a marker of GH sensitivity. J Clin Endocrinol Metab 2001;86:5176-5183.

40 Ranke MB, Traunecker R, Martin DD, Schweizer R, Schwarze CP, Wollmann HA, Binder G: IGF-I and IGF binding protein-3 levels during initial GH dosage step-up are indicators of GH sensitivity in GH-deficient children and short children born small for gestational age. Horm Res 2005;64:68-76.

-41 Haverkamp F, Gasteyger C: A review of biopsychosocial strategies to prevent and overcome early-recognized poor adherence in growth hormone therapy of children. J Med Econ 2011;14:448-457.

42 Clayton PE, Cuneo RC, Juul A, Monson JP, Shalet SM, Tauber M, European Society of Paediatric Endocrinology: Consensus statement on the management of the GH-treated adolescent in the transition to adult care. Eur J Endocrinol 2005;152:165-710.
3 Frindik JP, Baptista J: Adult height in growth hormone deficiency: historical perspective and examples from the national cooperative growth study. Pediatrics 1999;104:10001004.

-44 Bayley N, Pinneau SR: Tables for predicting adult height from skeletal age: revised for use with the Greulich-Pyle hand standards. J Pediatr 1952;40:423-441.

45 Tobiume H, Kanzaki S, Hida S, Ono T, Moriwake T, Yamauchi S, Tanaka H, Seino Y: Serum bone alkaline phosphatase isoenzyme levels in normal children and children with growth hormone $(\mathrm{GH})$ deficiency: a potential marker for bone formation and response to GH therapy. J Clin Endocrinol Metab 1997; 82:2056-2061.

46 Hermanussen M, Cole J: The calculation of target height reconsidered. Horm Res 2003; 59:180-183.

47 Rikken B, Massa GG, Wit JM: Final height in a large cohort of Dutch patients with growth hormone deficiency treated with growth hormone. Dutch Growth Hormone Working Group. Horm Res 1995;43:135-137.

48 Blethen SL, Baptista J, Kuntze J, Foley T, LaFranchi S, Johanson A: Adult height in growth hormone $(\mathrm{GH})$-deficient children treated with biosynthetic GH. The Genentech Growth Study Group. J Clin Endocrinol Metab 1997;82:418-420.

49 Reiter EO, Price DA, Wilton P, et al: Effect of growth hormone $(\mathrm{GH})$ treatment on the near-final height of 1258 patients with idiopathic GH deficiency: analysis of a large international database. J Clin Endocrinol Metab 2006;91:2047-2054.

-50 de Ridder MA, Stijnen T, Hokken-Koelega AC: Prediction of adult height in growth-hormone-treated children with growth hormone deficiency. J Clin Endocrinol Metab 2007;92: 925-931.

51 de Ridder MA, Stijnen T, Hokken-Koelega AC: Prediction model for adult height of small for gestational age children at the start of growth hormone treatment. J Clin Endocrinol Metab 2008;93:477-83.

52 Kriström B, Dahlgren J, Niklasson A, Nierop AF, Albertsson-Wikland K: The first-year growth response to growth hormone treatment predicts the long-term prepubertal growth response in children. BMC Med Inform Decis Mak 2009;9:1.

53 Ranke MB, Lindberg A, Price DA, Darendeliler F, Albertsson-Wikland K, Wilton P, Reiter EO, KIGS International Board: Age at growth hormone therapy start and first-year responsiveness to growth hormone are major determinants of height outcome in idiopathic short stature. Horm Res 2007;68:53-62.

54 Ranke MB, Price DA, Albertsson-Wikland K, Maes M, Lindberg A: Factors determining pubertal growth and final height in growth hormone treatment of idiopathic growth hormone deficiency. Analysis of 195 patients of the Kabi Pharmacia International Growth Study. Horm Res 1997;48:62-71.
55 Ranke MB, Lindberg A, KIGS International Board: Prediction models for short children born small for gestational age (SGA) covering the total growth phase. Analyses based on data from KIGS (Pfizer International Growth Database). BMC Med Inform Decis Mak 2011;11:38.

56 Ranke MB, Lindberg A, KIGS International Board: Height at start, first-year growth response and cause of shortness at birth are major determinants of adult height outcomes of short children born small for gestational age and Silver-Russell syndrome treated with growth hormone: analysis of data from KIGS. Horm Res Paediatr 2010;74:259-266.

57 Ranke MB, Lindberg A, Ferrández Longás A, Darendeliler F, Albertsson-Wikland K, Dunger D, Cutfield WS, Tauber M, Wilton P, Wollmann HA, Reiter EO, KIGS International Board: Major determinants of height development in Turner syndrome (TS) patients treated with GH: analysis of 987 patients from KIGS. Pediatr Res 2007;61:105-110.

58 Prader A, Largo RH, Molinari L, Issler C: Physical growth of Swiss children from birth to 20 years of age. First Zurich longitudinal study of growth and development. Helv Paediatr Acta 1989;52(Suppl):1-125.

59 Kastrup KW, Christiansen JS, Andersen JK, Orskov $\mathrm{H}$ : Increased growth rate following transfer to daily sc administration from three weekly im injections of hGH in growth hormone deficient children. Acta Endocrinol (Copenh) 1983;104:148-152.

60 Albertsson-Wikland K: The effect of human growth hormone injection frequency on linear growth rate. Acta Paediatr Scand Suppl 1987;337:110-116.

61 Albertsson-Wikland K, Westphal O, Westgren U: Daily subcutaneous administration of human growth hormone in growth hormone deficient children. Acta Paediatr Scand 1986; 75:89-97.

62 MacGillivray MH, Blethen SL, Buchlis JG, Clopper RR, Sandberg DE, Conboy TA: Current dosing of growth hormone in children with growth hormone deficiency: how physiologic? Pediatrics 1998;102:527-530.

63 Merriam GR, Wachter KW, Ma N, Liu L: Synchronization of hormonal time series: analytical approaches. Acta Paediatr Scand Suppl 1991;372:63-68.

64 Martha PM Jr, Gorman KM, Blizzard RM, Rogol AD, Veldhuis JD: Endogenous growth hormone secretion and clearance rates in normal boys, as determined by deconvolution analysis: relationship to age, pubertal status, and body mass. J Clin Endocrinol Metab 1992;74:336-344.

65 Albertsson-Wikland K, Rosberg S, Karlberg J, Growth T: Analysis of 24-hour growth hormone profiles in healthy boys and girls of normal stature: relation to puberty. J Clin Endocrinol Metab 1994;78:1195-1201.
Towards Optimal Treatment with GH in Short Children and Adolescents
Horm Res Paediatr 2013;79:51-67 DOI: $10.1159 / 000347121$ 
66 Veldhuis JD: Neuroendocrine control of pulsatile growth hormone release in the human: relationship with gender. Growth Horm IGF Res 1998;8(Suppl B):49-59.

-67 Veldhuis JD, Roemmich JN, Rogol AD: Gender and sexual maturation-dependent contrasts in the neuroregulation of growth hormone secretion in prepubertal and late adolescent males and females - a general clinical research centre-based study. J Clin Endocrinol Metab 2000;85:2385-2394.

68 Tanaka T: Global situation of growth hormone treatment in GHD children. Clin Pediatr Endocrinol 1990;8(suppl 13):59-65.

69 Root AW, Kemp SF, Rundle AC, Dana K, Attie KM: Effect of long-term recombinant growth hormone therapy in children - the National Cooperative Growth Study, USA, 1985-1994. J Pediatr Endocrinol Metab 1998; 11:403-412.

70 Juul A, Bernasconi S, Clayton PE, Kiess W, DeMuinck-Keizer Schrama S, Drugs and Therapeutics Committee of the European Society for Paediatric Endocrinology (ESPE): European audit of current practice in diagnosis and treatment of childhood growth hormone deficiency. Horm Res 2002;58:233241.

-71 Ranke MB, Reiter EO, Price DA: Idiopathic growth hormone deficiency in KIGS: selected aspects; in Ranke MB, Price DA, Reiter EO (eds): Growth Hormone Therapy in Pediatrics - 20 years of KIGS. Basel, Karger, 2007, pp 116-135.

72 Lindberg A, Ranke MB: Data analyses within KIGS; in Ranke MB, Price DA, Reiter EO (eds): Growth Hormone Therapy in Pediatrics - 20 Years of KIGS. Basel, Karger, 2007, pp 23-28.

-73 Bang P, Bjerknes R, Dahlgren J, Dunkel L, Gustafsson J, Juul A, Kriström B, Tapanainen P, Aberg V: A comparison of different definitions of growth response in short prepubertal children treated with growth hormone. Horm Res Paediatr 2011;75:335-345.

-74 Martin DD, Wit JM, Hochberg Z, Sävendahl L, van Rijn RR, Fricke O, Cameron N, Caliebe J, Hertel T, Kiepe D, Albertsson-Wikland K, Thodberg HH, Binder G, Ranke MB: The use of bone age in clinical practice - part 1. Horm Res Paediatr 2011;76:1-9.

-75 Martin DD, Wit JM, Hochberg Z, van Rijn RR, Fricke O, Weather G, Cameron N, Hertel T, Wudy SA, Butler G, Thodberg HH, Binder G, Ranke MB: The use of bone age in clinical practice - part 2. Horm Res Paediatr 2011;76: $10-16$.

76 Preece MA: The assessment of growth; in Ranke MB, Gunnarsson R (eds): Progress in Growth Hormone Therapy - 5 Years of KIGS. Mannheim, J\&J Verlag, 1994, pp 10-36.

77 Marshall WA: Evaluation of growth rate in height over periods of less than one year. Arch Dis Child 1971;46:414-420.
Kriström B, Karlberg J, Albertsson-Wikland $\mathrm{K}$ : Prediction of the growth response of short prepubertal children treated with growth hormone. Swedish Paediatric Study Group for GH Treatment. Acta Paediatr 1995;84:51-57.

79 Bakker B, Frane J, Anhalt H, Lippe B, Rosenfeld RG: Height velocity targets from the national cooperative growth study for first-year growth hormone responses in short children. J Clin Endocrinol Metab 2008;93:352-357.

80 Ranke MB, Lindberg A, KIGS International Board: Observed and predicted growth responses in prepubertal children with growth disorders: guidance of growth hormone treatment by empirical variables. J Clin Endocrinol Metab 2010;95:1229-1237.

81 Blethen SL, Compton P, Lippe BM, Rosenfeld RG, August GP, Johanson A: Factors predicting the response to growth hormone $(\mathrm{GH})$ therapy in prepubertal children with $\mathrm{GH}$ deficiency. J Clin Endocrinol Metab 1993;76: 574-579.

82 Ranke MB, Guilbaud O, Lindberg A, Cole T: Prediction of the growth response in children with various growth disorders treated with growth hormone: analyses of data from the Kabi Pharmacia International Growth Study. International Board of the Kabi Pharmacia International Growth Study. Acta Paediatr Suppl 1993;82(suppl) 391:82-88.

83 Ranke MB, Lindberg A: Predicting growth in response to growth hormone treatment. Growth Horm IGF Res 2009;19:1-11.

84 Schönau E, Westermann F, Rauch F, Stabrey A, Wassmer G, Keller E, Brämswig J, Blum WF, German Lilly Growth Response Study Group: A new and accurate prediction model for growth response to growth hormone treatment in children with growth hormone deficiency. Eur J Endocrinol 2001;144:13-20.

85 Wikland KA, Kriström B, Rosberg S, Svensson B, Nierop AF: Validated multivariate models predicting the growth response to $\mathrm{GH}$ treatment in individual short children with a broad range in GH secretion capacities. Pediatr Res 2000;48:475-484.

86 De Ridder MA, Stijnen T, Hokken-Koelega AC: Validation and calibration of the Kabi Pharmacia International Growth Study prediction model for children with idiopathic growth hormone deficiency. J Clin Endocrinol Metab 2003;88:1223-1227.

87 Dahlgren J, Kriström B, Niklasson A, Nierop AF, Rosberg S, Albertsson-Wikland K: Models predicting the growth response to growth hormone treatment in short children independent of GH status, birth size and gestational age. BMC Med Inform Decis Mak 2007; 7:40.

88 Land C, Blum WF, Shavrikova E, Kloeckner K, Stabrey A, Schoenau E: Predicting the growth response to growth hormone (GH) treatment in prepubertal and pubertal children with isolated GH deficiency - model validation in an observational setting (GeNeSIS). J Pediatr Endocrinol Metab 2007;20:685-693.
89 Kriström B, Dahlgren J, Niklasson A, Nierop AF, Albertsson-Wikland K: The first-year growth response to growth hormone treatment predicts the long-term prepubertal growth response in children. BMC Med Inform Decis Mak 2009;9:1

90 Wit JM, Kiess W, Mullis P: Genetic evaluation of short stature. Best Pract Res Clin Endocrinol Metab 2011;25:1-17.

91 Ranke MB, Lindberg A, Brosz M, Kaspers S, Loftus J, Wollmann H, Koltowska-Haggstrom M, Roelants M: Accurate long-term prediction of height during the first four years of growth hormone $(\mathrm{GH})$ treatment in prepubertal children with growth hormone deficiency (GHD) or Turner syndrome (TS). Horm Res Paediatr 2012;78:8-17.

-92 Kriström B, Jansson C, Rosberg S, Albertsson-Wikland K: Growth response to growth hormone $(\mathrm{GH})$ treatment relates to serum insulin-like growth factor I (IGF-I) and IGFbinding protein-3 in short children with various GH secretion capacities. Swedish Study Group for Growth Hormone Treatment. J Clin Endocrinol Metab 1997;82:2889-2898.

93 Schwarze CP, Wollmann HA, Binder G, Ranke MB: Short-term increments of insulin-like growth factor I (IGF-I) and IGF-binding protein-3 predict the growth response to growth hormone $(\mathrm{GH})$ therapy in $\mathrm{GH}$-sensitive children. Acta Paediatr 1999(Suppl); 88:200-208.

94 Ranke MB, Schweizer R, Elmlinger MW, Weber K, Binder G, Schwarze CP, Wollmann HA: Relevance of IGF-I, IGFBP-3, and IGFBP-2 measurements during GH treatment of GH-deficient and non-GH-deficient children and adolescents. Horm Res 2001;55: 115-124.

95 Cohen P, Rogol AD, Howard CP, Bright GM, Kappelgaard AM, Rosenfeld RG; American Norditropin Study Group: Insulin growth factor-based dosing of growth hormone therapy in children: a randomized, controlled study. J Clin Endocrinol Metab 2007;92: 2480-2486.

96 Clemmons DR: Consensus statement on the standardization and evaluation of growth hormone and insulin-like growth factor assays. Clin Chem 2011;57:555-559.

97 Juul A, Dalgaard P, Blum WF, Bang P, Hall K, Michaelsen KF, Müller J, Skakkebaek NE: Serum levels of insulin-like growth factor (IGF)binding protein-3 (IGFBP-3) in healthy infants, children, and adolescents: the relation to IGF-I, IGF-II, IGFBP-1, IGFBP-2, age, sex, body mass index, and pubertal maturation. J Clin Endocrinol Metab 1995;80:2534-2542.

98 Cohen P, Germak J, Rogol AD, Weng W, Kappelgaard AM, Rosenfeld RG, American Norditropin Study Group: Variable degree of growth hormone (GH) and insulin-like growth factor (IGF) sensitivity in children with idiopathic short stature compared with GH-deficient patients: evidence from an IGFbased dosing study of short children. J Clin Endocrinol Metab 2010;95:2089-2098. 
99 Ranke MB: Insulin-like growth factor 1 levels in patients within the KIGS database; in Ranke MB, Price DA, Reiter EO (eds): Growth Hormone Therapy in Pediatrics -20 Years of KIGS. Basel, Karger, 2007, pp 8392.

100 Kriström B, Aronson AS, Dahlgren J, Gustafsson J, Halldin M, Ivarsson SA, Nilsson NO, Svensson J, Tuvemo T, AlbertssonWikland K: Growth hormone (GH) dosing during catch-up growth guided by individual responsiveness decreases growth response variability in prepubertal children with GH deficiency or idiopathic short stature. J Clin Endocrinol Metab 2009;94:483-490.

101 Jung H, Land C, Nicolay C, De Schepper J, Blum WF, Schönau E: Growth response to an individualized versus fixed dose $\mathrm{GH}$ treatment in short children born small for gestational age: the OPTIMA study. Eur J Endocrinol 2009;160:149-156

102 Largo RH, Gasser T, Prader A, et al: Analysis of the adolescent growth spurt using smoothing spline functions. Ann Hum Biol 1978;5:421-434.

103 Martin DD, Hauspie RC, Ranke MB: Total pubertal growth and markers of puberty onset in adolescents with GHD: comparison between mathematical growth analysis and pubertal staging methods. Horm Res 2005; 63:95-101.
104 Veldhuis JD, Roemmich JN, Richmond EJ, Rogol AD, Lovejoy JC, Sheffield-Moore M, Mauras N, Bowers CY: Endocrine control of body composition in infancy, childhood, and puberty. Endocr Rev 2005;26:114-146.

105 Price DA, Jönsson P: Induction of puberty with sex steroids: a description of clinical practice recorded in KIGS (Pharmacia \& Upjohn International Growth Database). Biannual Report 1996, 2, N 14.

106 Kiess W, Conways G, Ritzen M, et al: Induction of puberty in the hypogonadal girls practices and attitudes of pediatric endocrinologists in Europe. Horm Res 2002;57:6671.

107 MacGillivray MH: Induction of puberty in hypogonadal children. J Pediatr Endocrinol Metab 2004;4(suppl):1277-1287.

108 Bourguignon JP: Linear growth as a function of age at onset of puberty and sex steroid dosage: the therapeutic implications. Endocr Rev 1988;9:467-488.

109 Ranke MB, Lindberg A: Observed and predicted total pubertal growth during treatment with growth hormone in adolescents with idiopathic growth hormone deficiency, Turner syndrome, short stature, born small for gestational age and idiopathic short stature: KIGS analysis and review. Horm Res Paediatr 2011;75:423-432.
10 Mauras N, Attie KM, Reiter EO, Saenger P, Baptista J: High dose recombinant human growth hormone (GH) treatment of GH-deficient patients in puberty increases near-final height: a randomized, multicenter trial. Genentech, Inc., Cooperative Study Group. J Clin Endocrinol Metab 2000;85:36533660.

111 Carel JC: Can we increase adolescent growth? Eur J Endocrinol 2004;151:U101U108.

112 Lee PA, Houk CP: Gonadotropin-releasing hormone analogue therapy for central precocious puberty and other childhood disorders affecting growth and puberty. Treat Endocrinol 2006;5:287-296.

113 Tanaka T: Sufficiently long-term treatment with combined growth hormone and gonadotropin-releasing hormone analog can improve adult height in short children with isolated growth hormone deficiency (GHD) and in non-GHD short children. Pediatr Endocrinol Rev 2007;5:471-481.

114 Mauras N, Gonzalez de Pijem L, Hsiang HY, Desrosiers P, Rapaport R, Schwartz ID, Klein KO, Singh RJ, Miyamoto A, Bishop K: Anastrozole increases predicted adult height of short adolescent males treated with growth hormone: a randomized, placebocontrolled, multicentre trial for one to three years. J Clin Endocrinol Metab 2008;93:823831. 